\title{
Kelola
}

\section{STRATEGI PENINGKATAN MUTU DAN CITRA (IMAGE) SEKOLAH DASAR NEGERI DI UNGARAN, SEMARANG}

\author{
Siti Maamarah \\ AlumniProgram Pascasarjana Magister Manajemen Pendidikan \\ FKIP-Universitas Kristen Satya Wacana \\ maamarahjpr@yahoo.com; \\ Supramono \\ Program Pascasarjana Magister Manajemen Pendidikan \\ FKIP-Universitas Kristen Satya Wacana \\ supramono@staff.uksw.edu
}

\begin{abstract}
This study aimed to determine the root of the problem of low quality and image of SDN 02 and 04 Ungaran and also to define the strategie to improve the quality and to build the image of SDN 02 and 04 Ungaran. This qualitative descriptive study used fishbone analysis and data collection used Focus Group Discussion (FGD), interviews, and study of document. The results showed that the root problem of low quality of SDN 02 and 04 Ungaran were learners had low ability, teachers provided less motivation of learning, the willingness of teachers to improve teaching skills were low, teachers were elderly, teachers did not plan learning activities by themselves, school principle had never participated in managerial training, non standard size of classrooms and the library had not been adequate. The root of the problem why the image of SDN Ungaran 02 and 04 were not good enough namely: the lack of academic supervition and extracurricular competent. Strategies to improve the quality and to build image of SDN 02 and 04 Ungaran were : a) implementing ongoing supervision by principle to raise teachers motivation, b) proposing for aid to the authorities both for the rehabilitation of classrooms and procurement of books, c) involving school committee in order to improve the school environment, and d) forming school developer team in academic achievement and extracurricular activities.
\end{abstract}

Keywords: Strategy, quality improvement, image improvement and Fishbone Analysis 


\section{PENDAHULUAN}

Setiap orang tua berpengharapan agar putra putrinya dapat diterima atau melanjutkan sekolah pada sekolah yang favorit dan mempunyai mutu yang bagus. Tidak mengherankan jika setiap awal tahun pelajaran orang tua disibukkan dengan urusan mencari sekolah untuk putra putri mereka. Tidak jarang orang tua rela mengeluarkan biaya yang cukup tinggi asalkan putra-putri mereka dapat diterima di sekolah yang bagus mutunya (Sunarko, 2009:177). Trimantara (2007:1) mengatakan ada lima aspek yang dipertimbangkan ketika orang tua memilih sekolah bagi putra-putri mereka yaitu, 1) kemampuan guru dalam mengajar, 2) lingkungan pergaulan peserta didik, 3) fasilitas/sarana, 4) citra sekolah, dan 5) penanaman nilai-nilai keagamaan. Sebagian besar orang tua akan memilih sekolah bagi putra-putrinya ke sekolah yang bermutu dengan melihat prestasi akademik sekolah, kegiatan ekstrakurikuler, dan kejuaraan lomba baik akademik maupun non akademik sekolah yang bersangkutan.

Menurut Arcaro (2007:1) mutu adalah sebuah proses terstruktur untuk menghasilkan keluaran yang dihasilkan. Sedang Hidayat dan Machali (2012:298) menyatakan mutu adalah totalitas dari karakteristik suatu produk yang menunjang kemampuannya untuk memuaskan kebutuhan yang ditetapkan. Sagala (2013:169) menyatakan bahwa mutu berkenaan dengan penilaian bagaimana suatu produk memenuhi kriteria, standar atau rujukan tertentu. Pengertian mutu menurut Sallis (2011:51-56) adalah konsep yang absolut dan relatif. Mutu dalam konsep absolut mempunyai pengertian bahwa mutu merupakan idealisme yang tidak dapat dikompromikan dan bagian dari standar tinggi yang tidak dapat diungguli, lebih tepat disebut "high quality" atau "top quality”. Dalam konsep relatif, mutu memiliki dua aspek yaitu menyesuaikan diri dengan spesifikasinya dan memenuhi kebutuhan pelanggan. Lebih lanjut Sallis mengatakan jika definisi mutu dipandang dari pelanggan adalah suatu yang memuaskan dan melampaui keinginan dan kebutuhan pelanggan.

Faktor yang mempengaruhi mutu pendidikan menurut Soedijarto (2008) meliputi proses pendidikan yang dialami peserta didik, ketersediaan sumber daya pendidikan termasuk di dalamnya tenaga pendidik, anggaran pendidikan, dan kebijakan yang merupakan hasil dari proses politik. Hal ini dipertegas oleh Sukmadinata (2008:7) yang menyatakan bahwa sekolah bermutu dipengaruhi oleh proses pendidikan yang bermutu dengan faktor pendukung, sarana dan prasarana dan biaya yang mencukupi, manajemen yang tepat, serta lingkungan yang mendukung. Faktor-faktor yang mempengaruhi mutu pendidikan digambarkan sebagai berikut. 


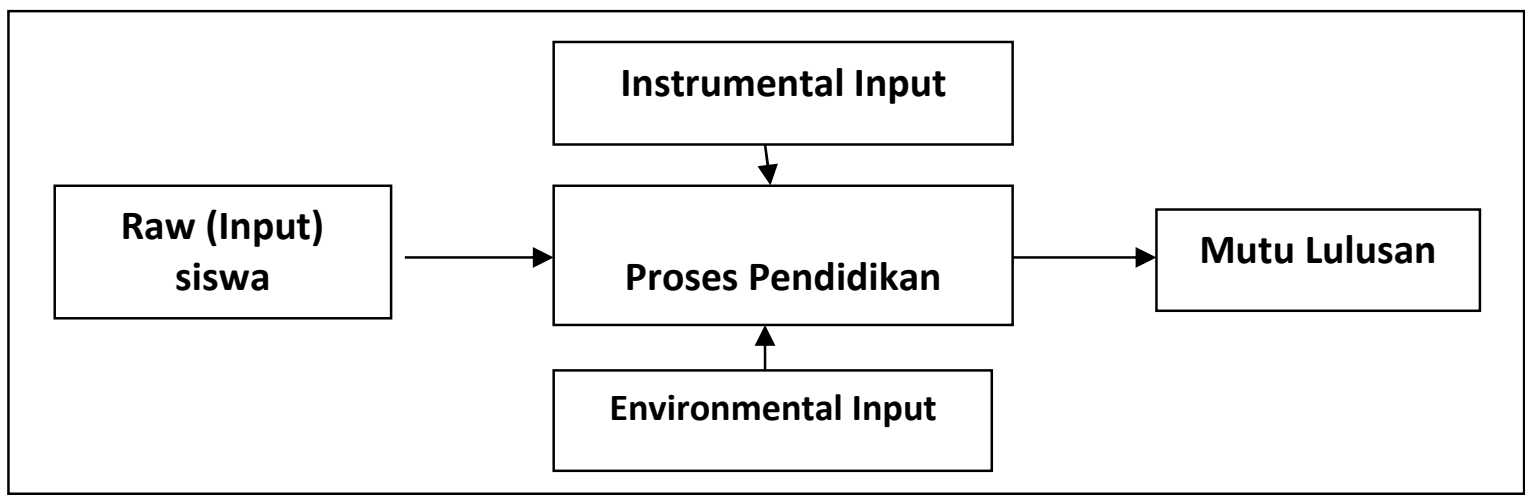

Gambar 1 Faktor-faktor yang Mempengaruhi Mutu Sumber: Sukmadinata (2008:7)

Tentang strategi, Gaffar dalam Sagala (2013:137) memberi pengertian bahwa strategi adalah rencana yang mengandung cara komprehensif dan integratif yang dapat dijadikan pegangan guna memenangkan kompetisi. Sementara Sagala (2013:137) merujuk pendapat Gaffar mengatakan bahwa strategi adalah rencana yang komprehensif mengintegrasikan segala resources dan capabilities yang mempunyai tujuan yang panjang untuk memenangkan kompetisi. Menurut Chandler (1962) yang dikutip olek Rangkuti (2008:3) strategi merupakan alat bantu mencapai tujuan perusahaan dalam kaitannya dengan tujuan jangka panjang, program tindak lanjut, serta prioritas alokasi sumber daya. Pendapat Chandler yang dikutip oleh Freddy Rangkuti ini selanjutnya yang digunakan dalam penelitian ini.

Tentang Manajemen Mutu, Edmond yang dikutip Abdillah (2008:33) menyatakan bahwa manajemen peningkatan mutu berbasis sekolah merupakan alternatif dalam pengelolaan pendidikan yang menekankan pada kemandirian dan kreativitas sekolah. Menurut Mulyasa (2012:11-14) manajemen peningkatan mutu berbasis sekolah sebagai model manajemen yang memberikan otonomi lebih besar kepada sekolah dan mendorong kepada sekolah untuk melakukan pengambilan keputusan secara partisipatif untuk mencapai tujuan mutu sekolah.

Selain mengutamakan mutu dalam memilih sekolah, para orang tua juga dipengaruhi oleh persepsi mereka terhadap citra (image) sekolah. Citra atau image sekolah bermutu menjadi salah satu hal penting dan menjadi pertimbangan orang tua ketika mereka memutuskan untuk memilih sekolah. Menurut Hidayat \& Machali (2012 : 248) citra (image) adalah impresi perasaan atau konsepsi yang ada pada publik mengenai perusahaan, suatu obyek, orang atau lembaga. Sedang menurut Kotler (2002:225) citra adalah seperangkat keyakinan, ide dan pengaruh yang didapat seseorang dari suatu obyek. Selanjutnya sikap dan tindakan seseorang terhadap obyek sebagian besar karena obyek tersebut, sedangkan citra merek merupakan syarat dari merek yang kuat dan persepsi yang relatif konsisten dalam jangka panjang (enduring perception). Di lain pihak Alifahmi (2005:73) menyatakan bahwa 
citra mencerminkan apa yang dipikirkan, emosi, dan persepsi individu. Walaupun orang melihat hal yang sama, tetapi pandangan mereka bisa berbeda. Persepsi inilah yang membentuk citra dari sebuah organisasi. Apabila citra yang baik sudah terbentuk maka secara otomatis akan menjadi iklan berjalan yang sangat efektif dan efisien, karena dengan pemasaran "Gethok Tular", maka pesan akan berjalan cepat dan sebuah pesan akan dianggap memiliki kredibilitas yang sangat tinggi apabila disampaikan oleh pihak ketiga.

Citra baik di mata orang tua dan peserta didik diperlukan oleh sebuah sekolah. Citra sekolah yang baik akan menjadi salah satu pertimbangan terjadinya pengambilan keputusan orang tua untuk menentukan pilihan terhadap sekolah tersebut. Hal ini didukung oleh pendapat Dharmmesta (1999) dalam Pramudyo (2012) bahwa apabila citra dari perusahaan tidak diragukan lagi kredibelitasnya, maka pembelian tidak lagi melalui pengambilan keputusan yang panjang. Pada kondisi ini jika diterapkan di sekolah dapat dikatakan bahwa apabila kepercayaan orang tua terhadap sekolah sudah terbentuk, maka orang tua cenderung memilih sekolah yang bersangkutan sebagai tempat mendidik putra-putri mereka.

Strategi sekolah dalam peningkatan citra (image) adalah dengan memberdayakan seluruh warga sekolah untuk berperan serta dalam memajukan sekolah, karena citra (image) terhadap sekolah terbentuk berdasarkan banyak unsur dalam bentuk komponen (Alifahmi, 2005:73). Dari banyaknya komponen dalam penelitian ini yang digunakan sebagai faktor yang mempengaruhi citra sekolah yaitu reputasi, ekstrakurikuler, biaya, perhatian guru, kondisi fisik, dan jangkauan Citra (image) sekolah dibangun dari persepsi masyarakat.

Persepsi masyarakat yang menganggap SDN Ungaran 02, 04 merupakan sekolah "kelas dua" merupakan citra negatif yang mempengaruhi kurang berminatnya orang tua peserta didik untuk menyekolahkan putra-putri mereka ke SDN Ungaran 02, 04. Hal ini dibuktikan dari semakin menurunnya jumlah peserta didik dari tahun ke tahun. Dari beberapa wawancara dengan informan tentang SDN Ungaran 02, 04 diperoleh informasi bahwa mutu sekolah ini memang dipersepsikan rendah. Pandangan tersebut sebenarnya dapat diterima, karena selama ini kegiatan lomba baik akademik (LCC, OSN, IMSO, Peserta Didik Berprestasi) maupun non akademik (Cipta Seni, Kreatifitas, Olahraga, Dokter Kecil, MAPSI, POPDA, Jambore, Pesta Siaga dll), SDN Ungaran 02, 04 belum mampu masuk ke peringkat sepuluh besar di tingkat kecamatan. Selain itu prestasi akademik (Ujian Sekolah) juga belum maksimal.

Beberapa penelitian terdahulu tentang mutu menggaris-bawahi pentingnya peningkatan mutu pada lembaga pendidikan, oleh sebab itu maka perlu adanya penelitian 
tentang strategi peningkatan mutu dengan terlebih dulu mencari akar permasalahannya. Berdasarkan uraian di atas maka perlu adanya penelitian tentang strategi peningkatan mutu dan citra (image) sekolah berdasarkan akar permasalahan dan persepsi orang tua peserta didik dengan analisis Fishbone di SDN Ungaran 02, 04. Adapun tujuan yang diharapkan dicapai melalui penelitian ini adalah untuk: (1) mengetahui akar masalah persepsi tentang rendahnya mutu SDN Ungaran 02, 04; (2) menentukan strategi peningkatan mutu di SDN Ungaran 02, 04; (3) mengetahui akar permasalahan kurang bagusnya citra (image) SDN Ungaran 02, 04; dan (4) menentukan strategi membangun citra (image) SDN Ungaran 02, 04.

\section{Metode Penelitian}

Jenis penelitian ini adalah penelitian deskriptif karena berupaya menggambarkan persepsi terhadap SDN Ungaran 02, 04. Data yang diperlukan dalam penelitian ini adalah data primer dan data sekunder. Data primer berupa hasil wawancara yaitu pengawas sekolah, tokoh masyarakat, guru, karyawan, dan orang tua peserta didik. Dalam penelitian ini data sekunder diperoleh dari studi dokumen yang berupa profil sekolah, data guru dan karyawan, data penerimaan peserta didik baru. Teknik pengumpulan data yang digunakan dalam penelitian ini adalah Focus Group Discussion (FGD), wawancara dan studi dokumen. Peserta FGD dalam penelitian ini adalah Kepala Sekolah (peneliti), Guru, Komite Sekolah, tokoh masyarakat dan pengawas sekolah. Teknik analisis data yang digunakan dalam penelitian ini adalah analisis Fishbone.

\section{Hasil Penelitian dan Pembahasan}

1. Akar Masalah Mutu Sekolah dipersepsikan Rendah

Focus Group Discussion (FGD) tentang mutu sekolah yang dipersepsikan rendah dilakukan di SDN Ungaran 02, 04 pada tanggal 25 Januari 2015. Peningkatan mutu sekolah dipengaruhi oleh 4 faktor yaitu: peserta didik (raw input), proses pendidikan, instrumental input, dan environmental input. Secara rinci hasil FGD tentang faktor penyebab yang mempengaruhi mutu sekolah dipersepsi rendah dapat dilihat pada diagram fishbone di Gambar 2 berikut. 


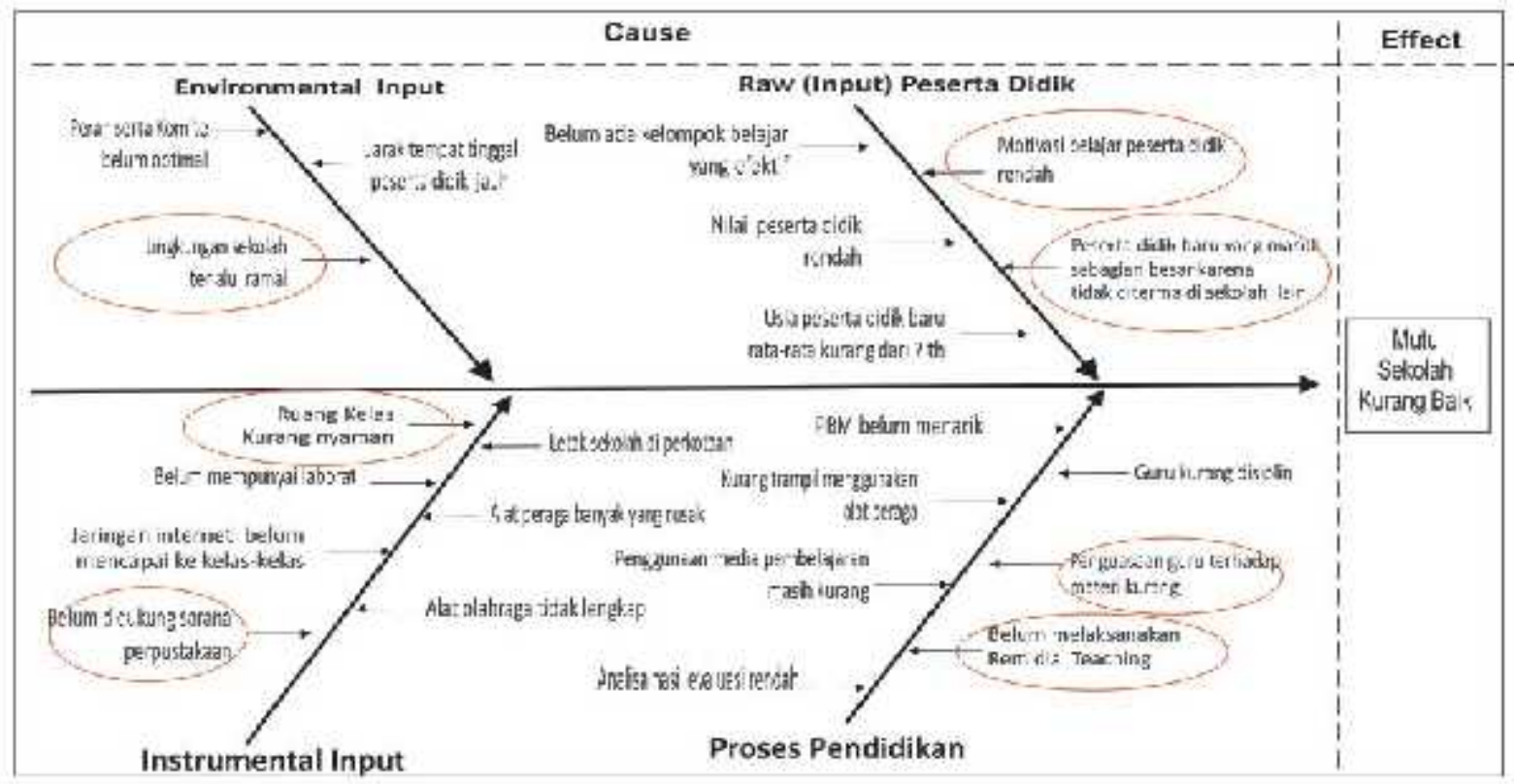

\section{Gambar 2 Analisis Fishbone hasil FGD Peningkatan Mutu Sekolah}

Dalam upaya menentukan strategi peningkatan mutu SDN Ungaran 02, 04 diperoleh beberapa akar permasalahan. Faktor (raw input) peserta didik disebabkan oleh motivasi belajar peserta didik rendah dan input yang masuk ke SDN Ungaran 02, 04 mempunyai kemampuan yang rendah. Akar permasalahannya yaitu guru terbiasa dengan rutinitas, kurang memberikan motivasi, puas dengan kemampuan yang dimikili, kemauan peningkatan keterampilan mengajar rendah, kemampuan dan kemauan menggunakan TIK rendah, peserta didik yang mendaftar mempunyai kemampuan rendah. Faktor proses pendidikan disebabkan oleh penguasaan guru terhadap materi kurang dan pelaksanaan remidi belum sesuai prosedur. Akar permasalahannya yaitu guru puas dengan kemampuan yang dimiliki, guru berusia lanjut, guru lebih suka mengajar dengan cara konvensional, guru belum menyusun rencana pembelajaran sendiri, guru belum melaksanakan analisis butir soal, soal evaluasi belum sesuai dengan rencana pembelajaran, dan kepala sekolah belum pernah mengikuti diklat manajerial. Faktor instrumental input disebabkan oleh ruang kelas kurang nyaman dan belum didukung oleh sarana perpustakaan yang memadai. Akar masalahnya yaitu ukuran ruang kelas tidak standar, perpustakaan belum memadai, dan buku banyak yang hilang atau rusak. Faktor environmental input disebabkan oleh lingkungan sekolah terlalu ramai. Akar masalahnya yaitu banyak pedagang kaki lima yang berjualan di sekitar sekolah.

\section{Akar Permasalahan Membangun Citra (Image) Sekolah}

Faktor yang mempengaruhi citra (image) sekolah ada enam yaitu reputasi sekolah, biaya, perhatian guru, kegiatan ekstrakurikuler, kondisi fisik sekolah dan jangkauan. Berdasarkan FGD yang dilakukan di SDN Ungaran 02, 04 dalam mencari akar masalah untuk 
membangun citra sekolah diperoleh hasil seperti pada diagram fishbone dalam Gambar 3 berikut.

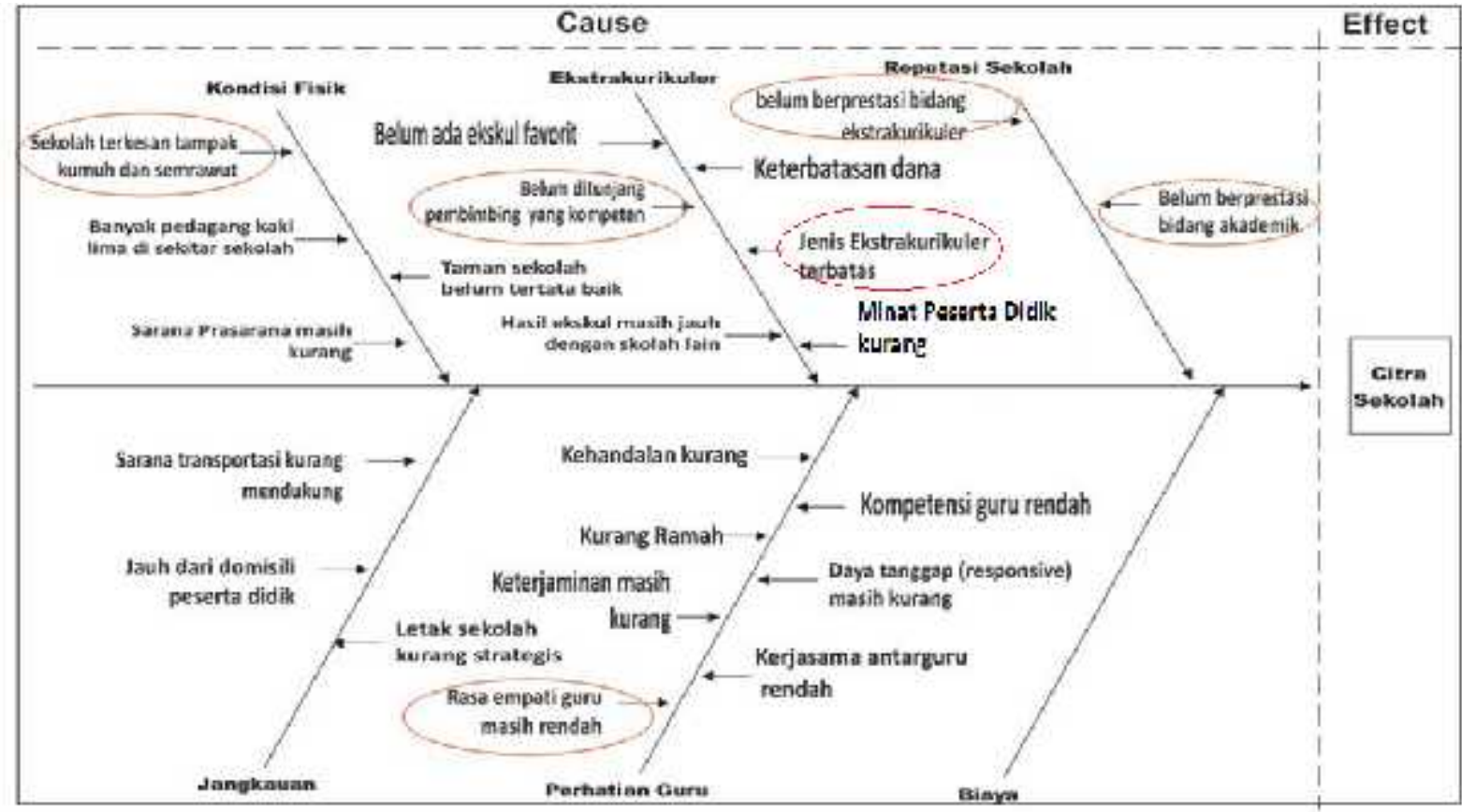

Gambar 3 Analisis Fishbone hasil FGD Membangun Citra (Image) Sekolah

Dalam upaya membangun citra (image) SDN Ungaran 02, 04 diperoleh hasil akar masalah yang ada di sekolah. Faktor reputasi sekolah disebabkan oleh prestasi dalam bidang akademik (UN) masih rendah dan belum berprestasi dalam bidang ekstrakurikuler. Akar masalahnya guru terbiasa dengan rutinitas dan disibukkan membuat administrasi, Guru kurang memberikan motivasi kepada peserta didik, Guru cukup puas dengan kemampuan yang dimiliki, kemauan guru peningkatan keterampilan mengajar kurang, Guru merasa pembelajaran konvensional sudah baik, kemampuan dan kemauan menggunakan TIK rendah.

Faktor biaya tidak dibahas karena sekolah sepenuhnya menggunakan dana BOS untuk operasionalnya. Faktor perhatian guru disebabkan karena rasa empati guru terhadap peserta didik kurang. Akar permasalahannya guru merasa segala sesuatu merupakan hal yang sudah biasa terjadi. Kurangnya rasa handarbeni (memiliki). Faktor ekstrakurikuler akar masalahnya guru merasa ekstrakurikuler bukan pada bidangnya, belum mempunyai pembimbing bidang akademik yang kompeten, dan keterbatasan dana. Faktor kondisi fisik disebabkan oleh lingkungan luar sekolah dan lingkungan dalam sekolah. Akar masalahnya banyaknya pedagang kaki lima yang berda di sekitar sekolah, kamar mandi/WC peserta didik belum memenuhi rasio perbandingan peserta didik. Sedang faktor jangkauan tidak mempengaruhi citra (image) sekolah.

Pembahasan

1. Strategi Peningkatan Mutu Sekolah 
Dalam upaya peningkatan mutu di SDN Ungaran 02, 04 perlu adanya kerja sama antaran kepala sekolah, para guru/karyawan, peserta didik dan orang tua peserta didik (masyarakat). Masing-masing komponen saling berkaitan dan saling mempengaruhi keberhasilan dalam peningkatan mutu secara keseluruhan. Akar masalah penyebab mutu dipersepsikan rendah dari peserta didik (raw input) yaitu guru. Guru terbiasa dengan rutinitas dan disibukkan membuat administrasi, kemauan guru peningkatan keterampilan mengajar rendah, guru merasa pembelajaran dengan cara konvensional sudah baik, dan kemampuan serta kemauan guru menggunakan Teknik Informatika (TIK) rendah. Akar permasalahan tersebut menjadikan motivasi belajar peserta didik SDN Ungaran 02, 04 rendah. Hal itu terjadi karena program supervisi sudah ada, namun pelaksanaannya belum sesuai dengan program. Kepala sekolah disibukkan dengan banyaknya laporan dan administrasi yang harus dikerjakan. Seperti Dapodik, Padamu Negeri, dan BOS. Selain itu juga adanya kurang percaya diri dan rasa kurang enak dari kepala sekolah karena faktor senioritas. Guna peningkatan motivasi belajar peserta didik SDN Ungaran 02, 04, strategi yang disarankan salah satunya yaitu melaksanakan supervisi akademik berkelanjutan agar pembelajaran dapat dilaksanakan secara optimal.

Kepala Sekolah mempunyai peran sebagai supervisor sekaligus sebagai motivator. Sebagai supervisor kepala SDN Ungaran 02, 04 dapat membina keprofesionalan guru melalui supervisi akademik berkelanjutan agar terjadi peningkatan kualitas dan mutu pendidikan melalui kegiatan belajar mengajar. Teknik supervisi dapat dilakukan dengan kunjungan kelas, ini dimaksudkan untuk mengumpulkan informasi dalam rangka peningkatan mutu proses dan hasil belajar sebagai tanggungjawab bersama. Peran kepala sekolah sebagai motivator hendaknya dapat membangkitkan semangat dan memotivasi guru untuk terus berprestasi, sehingga guru mempuyai motivasi berprestasi. Motivasi berprestasi menurut McClelland (1987) dalam Mayangsari (2013) adalah suatu keinginan yang ada dalam diri seseorang yang mendorong orang tersebut untuk berusaha mencapai suatu standar atau ukuran keunggulan. Pencapaian prestasi (achievement) tidak selalu berupa pencapaian sasaran yang ditetapkan tetapi bergantung pada kesiapan guru dalam mengerjakan tugas. Guru didorong mempraktekkan gagasan inovatif yang dapat peningkatan mutu pembelajaran.

Teknik memotivasi dapat dilakukan sebelum supervisi, bersamaan pelaksanaan supervisi, atau sesudah supervisi. Pelaksanaan supervisi dapat dengan pertemuan individual, dialog, tukar pikiran mengenai usaha untuk peningkatan kemampuan profesioanal guru dalam upaya peningkatan mutu pembelajaran. Supervisi akademik yang dilaksanakan dapat 
peningkatan keterampilan guru dalam mengajar dan dapat memotivasi guru untuk melaksanakan pembelajaran yang inovatif. Dengan pembelajaran yang inovatif tentunya dapat peningkatan motivasi belajar peserta didik dan pada akhirnya dapat peningkatan mutu.

Dalam peningkatan mutu pembelajaran SDN Ungaran 02, 04 guru dapat memberikan perhatian kepada peserta didik dengan pembimbingan kelompok maupun individual. Seperti yang disampaikan Ried (2009:103) merasa senang merupakan hal penting bagi peserta didik, merasa nyaman dapat membuat peserta didik belajar lebih efektif. Dengan perhatian, rasa senang, nyaman, dan perasaan terlindungi yang diberikan guru maka akan peningkatan motivasi belajar peserta didik, dan tentunya akan peningkatan hasil belajar peserta didik.

Berdasarkan penelitian terdahulu yang dilakukan oleh Dwija (2008) menyatakan peranan motivasi berprestasi sangat penting dan bermakna dalam mendorong peserta didik untuk melakukan usaha sebaik-baiknya atas dasar kompetensi yang sehat dan bertanggung jawab agar tercapai hasil belajar yang maksimal. Motivasi dapat mempengaruhi apa yang kita pelajari, kapan kita belajar, dan bagaimana cara kita belajar (Schunk, 2012:7). Pujian diberikan kepada peserta didik untuk sesuatu yang dapat dilakukan oleh peserta didik. Idealnya motivasi harusnya intrinsik yakni, peserta didik memiliki motivasi dari dalam diri (self motivating) (Reid, 2009:19). Memotivasi peserta didik dapat dilakukan dengan cara pemberian penghargaan (reward) merupakan motivasi ekstrinsik kepada peserta didik. Menurut peneliti guru dapat memberikan motivasi dalam bentuk apapun agar motivasi dari dalam diri peserta didik muncul lebih kuat. Dengan adanya motivasi dari dalam dirinya sendiri peserta didik akan lebih efektif dalam belajar dan lebih mandiri, sehingga prestasi belajarnya pun akan meningkat.

Akar masalah kemampuan dan kemauan guru SDN Ungaran 02, 04 menggunakan teknik informatika (TIK) rendah. Hal itu terjadi karena sebagian besar guru sudah berusia lanjut, bahkan mendekati masa pensiun. Strategi yang disarankan yaitu melakukan pendekatan personal. Kepala sekolah memberikan motivasi kepada guru agar mau mengikuti pelatihan menggunakan TIK di sekolah dengan dipandu guru yang menguasai TIK, Operator Sekolah (OPS), dan tenaga administrasi sekolah.

Akar masalah peserta didik (raw input) selanjutnya yaitu peserta didik yang mendaftar di SDN Ungaran 02, 04 tidak lolos tes seleksi di sekolah lain, sehingga input yang masuk ke sekolah mempunyai kemampuan yang rendah. Hal tersebut terjadi karena sekolah favorit disekitar Ungaran melaksanakan tes seleksi pada saat Pendaftaran Peserta Didik Baru (PPDB). Strategi yang disarankan yaitu peningkatan Proses Belajar Mengajar (PBM) dengan 
menerapkan Pembelajaran Aktif Inovatif Kreatif dan Menyenangkan (PAIKEM) di sekolah dan menerapkan budaya mutu di sekolah. Dalam menerapkan PAIKEM di SDN Ungaran 02, 04 di dalam kelas seharusnya sesuai dengan standar proses meliputi perencanaan proses pembelajaran, pelaksanaan proses pembelajaran, penilaian hasil pembelajaran, dan pengawasan proses pembelajaran. Perencanaan proses pembelajaran diawali dari penyusunan rencana pelaksanaan pembelajaran (RPP) merupakan penjabaran dari silabus. RPP disusun secara lengkap dan sistematis supaya pelaksanaan pembelajaran dapat berlangsung secara interaktif, menyenangkan, memberi ruang untuk kreativitas, dan kemandirian sesuai dengan bakat, minat dan karakteristik peserta didik.

Namun kenyataanya di SDN Ungaran 02, 04 sebagian guru belum menyususn RPP sendiri. Seharusnya RPP disusun oleh guru secara sistematis, sesuai antara kompetensi, tujuan pembelajan dan evaluasi dengan karakteristik peserta didik. Selanjutnya didukung dengan media pembelajaran yang inovatif. Kendalanya kemauan guru untuk melakukan inovasi rendah, dengan alasan faktor usia. Penilaian hasil pembelajaran belum dilakukan secara konsisten, sistematik, dan terprogram. Perlu juga pengawasan proses pembelajaran oleh kepala sekolah atau pengawas sekolah melalui supervisi akademik berkelanjutan. Kepala Sekolah sebagai pemimpin dalam menerapkan budaya mutu di sekolah terlebih dahulu bersama-sama steakholdes (kepala sekolah, guru, dan komite sekolah) meninjau kembali Visi, Misi dan tujuan sekolah apakah sudah sesuai dengan yang diharapkan oleh seluruh warga sekolah, sesuai dengan upaya peningkatan mutu dan citra (image) sekolah. Selanjutnya dalam menerapkan budaya mutu di sekolah perlu adanya kerja sama tim (team work) yang terdiri dari kepala sekolah, para guru, karyawan, dan orang tua peserta didik (masyarakat). Masingmasing komponen saling berkaitan dan saling mempengaruhi keberhasilan dalam peningkatan mutu secara keseluruhan. Akar masalah peserta didik baru yang masukke SDN Ungaran 02, 04 karena tidak diterima di sekolah lain dan peserta didik yang mendaftar ke sekolah jumlahnya terbatas. Strategi yang disarankan yaitu sekolah mengadakan promosi. Mengadakan sosialisasi penerimaan peserta didik baru (PPDB). Menyebarkan brosur atau liflet.

Akar masalah penguasaan guru terhadap materi kurang, akar permasalahannya yaitu guru merasa cukup puas dengan kemampuan yang dimiliki, guru sebentar lagi menjelang pensiun, guru merasa mengajar dengan cara konvensional sudah bagus dan berhasil. Akar permasalahan ini pada dasarnya sama dengan akar permasalahan pada faktor peserta didik (raw input) dengan sebab motivasi belajar peserta didik rendah. Strategi yang disarankan juga 
sama yaitu Kepala Sekolah melaksanakan supervisi berkelanjutan dengan membangkitkan motivasi guru untuk peningkatan kemampuannya. Dengan pendekatan personal, guru senior merasa lebih dihargai dan tidak ada kesan mendapatkan perintah dari yang lebih muda atau terbebani atas tugas dan tanggungjawabnya. Guru dengan penuh tanggungjawab melaksanakan tugas yang sudah menjadi kewajibannya.

Akar permasalahan dari pelaksanaan remedial belum sesuai prosedur yaitu guru belum menyusun Rencana Pelaksanaan Pembelajaran (RPP) sendiri, guru belum melaksanakan analisis perbutir soal. Soal evaluasi tidak sesuai yang terdapat pada RPP. Hal itu dikarenakan RPP yang dimiliki guru bukan buatan guru sendiri, maka soal evaluasi tidak sesuai dengan tujuan pembelajaran. Strategi yang disarankan kepala sekolah melaksanakan supervisi berkelanjutan dengan pendampingan dari pengawas sekolah. Tekniknya kepala sekolah melaksanakan supervisi sesuai dengan program yang telah disusun bekerjasama dengan pengawas sekolah. Pelaksanaannya dapat secara bersamaan pada saat pembinaan dinas di SDN Ungaran 02, 04 bersama-sama antara Pengawas Sekolah dan Kepala Sekolah. Dalam pembinaan diprogramkan adanya penyegaran kembali cara menyusun RPP. RPP disusun secara lengkap dan sistematis supaya pelaksanaan pembelajaran dapat berlangsung secara interaktif, menyenangkan, memberi ruang untuk kreativitas, dan kemandirian sesuai dengan bakat dan minat peserta didik. Pada kegiatan inti gunakan metode yang sesuai dengan karakteristik peserta didik dan mata pelajaran yang dapat meliputi proses eksplorasi, elaborasi dan konfirmasi. Penilaian hasil pembelajaran dilakukan secara konsisten, sistematik, dan terprogram. Setelah penyusunan RPP mengadakan peer teaching bersama teman sejawat sebagai peserta didik sekaligus nantinya akan memberikan masukan atau evaluasi.

Akar masalah ukuran luas ruang kelas tidak sesuai standar dan ada beberapa ruang kelas yang rusak menjadikan ruang kelas kurang nyaman. Strategi yang disarankan yaitu membuat ruang kelas menjadi nyaman. Cara membuat ruang kelas menjadi nyaman yaitu dengan pemasangan kipas angin, ventilasi dan pencahayaan cukup. Sedang ruang kelas yang rusak strateginya dengan cara mengajukan bantuan rehap kepada dinas terkait. Akar permasalahan faktor instrumental input SDN Ungaran 02, 04 baru memiliki gedung perpustakaan, buku referensi maupun buku pegangan peserta didik banyak yang rusak atau hilang. Strategi yang disarankan yaitu mengajukan proposal bantuan buku ke dinas terkait. Menerima sumbangan suka rela dari alumni. Mengalokasikan dana BOS 5\% dari seluruh anggaran untuk penggantian buku peserta didik yang rusak atau buku yang hilang sehingga memenuhi perbandingan jumlah buku dan jumlah peserta didik 1:1. 
Akar masalah faktor environmental input yaitu banyak pedagang kaki lima yang berjualan di sekitar SDN Ungaran 02, 04, jam pelajaran antara SD, SMP dan SMK waktunya tidak sama, jam istirahat juga tidak bersamaan, orang tua peserta didik SDN Ungaran 02, 04 yang kebanyakan ibu-ibu penjemput suka mengelompok membicarakan hal-hal yang kurang perlu. Masalah tersebut menimbulkan suara berisik atau gaduh. Strategi yang disarankan yaitu peran serta komite SDN Ungaran 02, 04 dalam penertiban pedagang kaki lima supaya tidak ada konflik kepentingan.

2. Strategi Membangun Citra (image) Sekolah

Citra (image) sekolah menjadi salah satu hal penting dan menjadi pertimbangan orang tua ketika mereka memutuskan untuk memilih sekolah. Dalam upaya membangun citra (image) di SDN Ungaran 02, 04 perlu adanya kerja sama antaran kepala sekolah, para guru/karyawan, peserta didik dan orang tua peserta didik (masyarakat). Masing-masing komponen saling berkaitan dan saling mempengaruhi keberhasilan dalam peningkatan mutu secara keseluruhan. Sesuai dengan hasil FGD Citra (image) sekolah dipengaruhi oleh ada enam faktor yaitu reputasi sekolah, biaya, perhatian guru, kegiatan ekstrakurikuler, kondisi fisik sekolah dan jangkauan.

Akar permasalahan dari prestasi bidang akademik Ujian Sekolah (US) SDN Ungaran 02, 04 rendah pada dasarnya sama dengan akar permasalahan membangun citra (image) SDN Ungaran 02, 04 dilhat dari faktor peserta didik. Akar masalahnya yaitu guru terbiasa dengan rutinitas dan disibukkan membuat administrasi, guru merasa puas dengan kemampuan yang dimilikinya, kemauan guru peningkatan keterampilan mengajar rendah, guru merasa pembelajaran dengan cara konvensional sudah baik, dan kemampuan serta kemauan guru menggunakan Teknik Informatika (TIK) rendah. Akar permasalahan tersebut menjadikan motivasi belajar peserta didik rendah. Guna peningkatan motivasi belajar peserta didik strategi yang disarankan yaitu Kepala Sekolah melaksanakan supervisi berkelanjutan supaya pembelajaran dapat dilaksanakan secara optimal. Strategi yang digunakan dalam dalam penyelesaian masalah sebenarnya juga sama, yaitu melaksanakan supervisi akademik berkelanjutan dengan lebih menekankan pada pemberian motivasi. Motivasi agar guru dalam melaksanakan tugasnya lebih profesional. Dengan keprofesionalan guru SDN Ungaran 02, 04 akan dapat peningkatan kesan positif terhadap kompetensi yang dimiliknya. Kesan bahwa guru tidak gagap teknologi (Gaptek) yaitu dengan cara melaksanakan pembelajaran inovatif dengan menggunakan media yang bervariasi dan berbasis TIK. Hal ini akan menambah citra (image) positif terhadap SDN Ungaran 02, 04. 
Pembelajaran yang inovatif akan peningkatan nilai ujian, dengan meningkatnya nilai ujian tentunya banyak peserta didik yang diterima di sekolah lanjutan yang favorit. Hal ini akan dapat menarik calon peserta didik baru untuk mendaftar di SDN Ungaran 02, 04. Biasanya orang tua peserta didik dalam mencarikan sekolah untuk putranya dengan mencari tahu berapa hasil ujian tahun terakhir. Hasil ujian SDN Ungaran 02, 04 yang tinggi dan peringkat sekoah naik peningkatan citra (image) sekolah dimata masyarakat. Akar masalah belum mempunyai pembimbing bidang akademik yang kompeten dengan strategi membentuk tim pengembang prestasi sekolah dibidang akademik. Tim pengembang bidang kademik terdiri dari guru-guru yang akan bekerjasama dalam mengupayakan meningkatnya prestasi akademik khususnya nilai ujian. Dapat juga dibentuk guru mata pelajaran khusus untuk kelas enam agar penguasaan peserta didik terhadap materi yang akan diujikan lebih dalam.

Akar masalah bidang ekstrakurikuler yang menyebabkan bidang ekstrakurikuler SDN Ungaran 02, 04 belum berprestasi yaitu keterbatasan dana, guru merasa bukan dalam bidangnya dalam membimbing ekstrkurikuler, faktor usia karena guru menjelang pensiun, jenis ekstrakurikuler kurang menarik, dan pembimbing ekstrakurikuler kurang kompeten. Strategi yang disarankan yaitu sekolah membentuk tim pengembang bidang ekstrakurikuler. Untuk mengatasi keterbatasan dana, kegiatan ekstrakurikuler yang dapat dibimbing sendiri oleh tim pengembang, dibimbing sendiri dengan terlebih dahulu mengirim untuk mengikuti diklat. Sedangkan kegiatan yang tidak dikuasai oleh tim pengembang dapat mengundang pelatih atau pembina dari pihak luar sekolah, dinas terkait ataupun bekerjasama dengan orang tua peserta didik yang mempunyai kompetensi dibidang ekstakurikuler. Akar masalah biaya SDN Ungaran 02, 04 sebenarnya membawa citra (image) positif, sebab sekolah menerima dana BOS dari pemerintah sehingga biaya operasional sekolah SDN Ungaran 02, 04 didanai dari dana BOS, maka dengan adanya dana BOS tidak ada pungutan terhadap pesertra didik.

Akar masalah rasa empati guru SDN Ungaran 02, 04 terhadap peserta didik rendah yaitu guru merasa segala sesuatu merupakan hal yang sudah biasa terjadi dan guru kurang merasa handarbeni (rasa memiliki), strategi yang disarankan yaitu Kepala Sekolah SDN Ungaran 02, 04 melaksanakan supervisi akademik berkelanjutan dan dapat membangkitkan motivasi guru untuk berprestasi maupun membangkitkan rasa handarbeni (memiliki). Kepala sekolah SDN Ungaran 02, 04 sebagai motivator hendaknya dapat membangkitkan semangat dan memotivasi guru untuk terus berprestasi, sehingga guru mempuyai motivasi berprestasi. Motivasi berprestasi menurut McClelland (1987) dalam Mayangsari (2013) adalah suatu keinginan yang ada dalam diri seseorang yang mendorong orang tersebut untuk berusaha 
mencapai suatu standar atau ukuran keunggulan. Pencapaian prestasi (achievement) tidak selalu berupa pencapaian sasaran yang ditetapkan tetapi bergantung pada kesiapan mengerjakan tugas. Guru didorong untuk mempraktekkan gagasan inovatif yang dapat peningkatan mutu pembelajaran. Teknik memotivasi dapat dilakukan bersamaan pelaksanaan supervisi dengan pertemuan individual, dialog, tukar pikiran mengenai usaha untuk peningkatan kemampun profesioanal guru dalam upaya peningkatan mutu pembelajaran. Pertemuan dapat bersifat informal sebelum atau sesudah kunjungan kelas.

Akar permasalahan dari faktor ekstrakurikuler di SDN Ungaran 02, 04 yaitu guru merasa ekstrakurikuler yang ada bukan bidangnya, guru yang diharapkan sebagai pembimbing menjelang pensiun, dan keterbatasan dana. Akar permasalahan ini sama dengan akar permasalahan reputasi sekolah dipersepsikan kurang bagus karena kegiatan ekstrakurikuler di SDN Ungaran 02, 04 belum dapat berprestasi. Strategi yang disarankan yaitu membentuk tim pengembang kegiatan ekstrakurikuler. Kegiatan ekstrakurikuler yang diminati oleh peserta didik harapannya dapat dikembangkan sampai benar-benar dapat memberikan kesan baik atau citra positif bagi SDN Ungaran 02, 04. Kegiatan yang sudah dilaksanakan yaitu bekerjasama dengan dinas pemuda dan olahraga (Dispora) untuk mengadakan kegiatan ekstrakurikuler taekwondo di SDN Ungaran 02, 04. Hasilnya sudah cukup membanggakan. Kegiatan taekwondo di SDN Ungaran 02, 04 baru dilaksanakan satu semester, dari peserta yang diikutkan kejuaraan tingkat Jawa Tengah ada lima peserta didik yang mendapat medali. Tiga peserta didik mendapat medali emas dan dua peserta didik mendapat medali perak. Hal tersebut dapat peningkatan reputasi SDN Ungaran 02, 04 menjadi lebih baik.

Kondisi fisik SDN Ungaran 02, 04 yang mempengaruhi citra (image) sekolah yaitu lingkungan luar sekolah dan lingkungan dalam sekolah. Akar masalah dari lingkungan luar sekolah yaitu banyak pedagang kaki lima yang berjualan disekitar sekolah, strategi yang disarankan yaitu penertiban pedagang kaki lima bekerjasama dengan komite sekolah. Akar masalah lingkungan di dalam SDN Ungaran 02, 04 tampak kotor yaitu dana BOS tidak boleh digunakan untuk pembuatan taman sekolah, sehingga taman sekolah belum tertata dengan baik. Strategi yang disarankan mengadakan gerakan menanam dan merawat. Akar masalah yang lain yaitu kamar mandi/WC peserta didik SDN Ungaran 02, 04 belum memenuhi rasio perbandingan jumlah siswa dengan jumlah kamar mandi/WC. Strategi yang disarankan dengan mengajukan prososal ke Dinas Pendidikan untuk pengadaan kamar mandi/WC. Faktor jangkauan bagi SDN Ungaran 02, 04 tidak mempengaruhi citra (image) sekolah, karena letak 
sekolah mudah dijangkau dengan kendaraan. Bagi peserta didik yang jarak rumah dengan sekolah cukup jauh pada umumnya sudah mempunyi alternatif cara berangkat sekolah.

\section{SIMPULAN}

\section{Peningkatan Mutu Sekolah}

Hasil penelitian dalam upaya menentukan strategi peningkatan mutu SDN Ungaran 02, 04 diperoleh beberapa akar permasalahan diantaranya yaitu guru terbiasa dengan rutinitas, kurang memberikan motivasi, puas dengan kemampuan yang dimikili, peserta didik yang mendaftar mempunyai kemampuan rendah. Guru belum menyusun rencana pembelajaran sendiri, guru belum melaksanakan analisis perbutir soal, kepala sekolah belum pernah mengikuti diklat manajerial. Ukuran ruang kelas tidak standar dan perpustakaan belum memadai. Banyak pedagang kaki lima yang berjualan di sekitar sekolah.

Strategi untuk peningkatan mutu diantaranya yaitu kepala sekolah melaksanakan supervisi dengan pendekatan personal secara berkelanjutan untuk membangkitkan motivasi guru dan menerapkan budaya mutu. Guru memberikan perhatian kepada peserta didik, memberikan motivasi kepada peserta didik, menerapkan PAIKEM. Selanjutnya mengusahakan kenyamanan ruang kelas dan mengalokasikan dana BOS sebesar $5 \%$ untuk penggantian buku rusak. Berikutnya melibatkan komite sekolah untuk ketertiban lingkungan sekolah.

\section{Membangun Citra (Image) Sekolah}

Akar permasalahan dalam upaya membangun citra (image) SDN Ungaran 02, 04 di antaranya adalah: a) guru terbiasa dengan rutinitas dan disibukkan membuat administrasi, b) Guru kurang memberikan motivasi kepada peserta didik, c) Guru cukup puas dengan kemampuan yang dimiliki, d) belum mempunyai pembimbing bidang akademik yang kompeten, dan jenis ekstrakurikuler kurang menarik. Dari segi faktor perhatian guru akar masalahnya adalah Guru merasa segala sesuatu merupakan hal yang sudah biasa terjadi, kurangnya rasa handarbeni (memiliki). Dalam faktor ekstrakurikuler akar masalahnya Guru merasa ekstrakurikuler bukan pada bidangnya. Faktor kondisi fisik mencakup lingkungan luar sekolah dan lingkungan dalam sekolah. Akar masalahnya banyaknya pedagang kaki lima yang berada di sekitar sekolah. Faktor biaya dan jangkauan tidak mempengaruhi citra (image) sekolah.

Strategi untuk membangun citra (image) sekolah diantaranya yaitu a) kepala sekolah melaksanakan supervisi berkelanjutan dengan membangkitkan motivasi guru untuk peningkatan kemampuannya dan senantiasa berinovasi dalam pembelajaran, b) Guru memberikan perhatian kepada peserta didik, c) Guru memberikan motivasi kepada peserta 
didik, d) mengadakan pelatikan penggunaan TIK, e) membentuk tim pengembang prestasi sekolah bidang akademik dan ekstrakurikuler, f) memberdayakan orang tua peserta didik, g) bekerjasama dengan instansi lain dan g) mengadakan penertiban pedagang kaki lima dengan melibatkan Komite Sekolah.

\section{Daftar Pustaka}

Abdhilah, F,.2008. Pengertian Manajemen Mutu Berbasis Sekolah. Surabaya. Elkaf

Alifahmi, H., 2008. Marketing Communications Orchresta. Harmonisasi Iklan, Promosi, dan Marketing Publik Relations. Bandung. Examedia Publishing (Grup Sygma)

Arcaro, S. J., 2007. Pendidikan Berbasis Mutu. Prinsip-prinsip Perumusan dan Tata Langkah Penerapan. Yogyakarta: Pustaka Pelajar.

Dwija, I W., 2008. Hubungan Antara Konsep Diri, Motivasi Berprestasi dan Perhatian Orang Tua Dengan Hasil belajar Sosiologi Pada Siswa Kelas II SekolahMenengah Atas Unggulan Di Kota Amlapura. Jurnal Pendidikan dan Pengajaran UNDHIKSA, No 1 TH XXXXI Januari 2008, ISSN 0215-8250.

Hidayat, A. \& Machali, H., 2012. Pengelolaan Pendidikan. Konsep, Prinsip, dalam Mengelola Sekolah dan Madrasah. Yogyakarta: Kaukaba. Cetakan I

Kusdiyanto, 2008. Citra Perguruan Tinggi Swasta Di Kopertis Wilayah VI Jawa Tengah. BENEFIT Jurnal Manajemen dan Bisnis Volume 12, Nomor 2, Desember 2008.

Kotler, P., 2002. Manajemen Pemasaran Edisi Millenium. Alih bahasa Hendra Teguh, Prenhalindo, Jakarta

Mayangsari, M.D,, 2013 Motivasi Berprestasi Mahasiswa Ditinjau Dari Penerimaan Orang Tua. Jurnal Ecopsy, Volume 1,Nomor 1, Desember 2013

Mulyasa, E, 2012. Manajemen Berbasis Sekolah. Konsep, Strategi dan Implementasi. PT Remaja Rosdakarya, Bandung.

Pramudyo, A., 2012. Pengaruh Citra Merek Terhadap Loyalitas Melalui Kepuasan Sebagai Intervening (Studi pada Mahasiswa Perguruan Tinggi Swasta di Yogyakarta). JBMA-Vol.I, No. 1, 1 Agustus 2012.

Rangkuti, F., 2013. Analisis SWOT. Jakarta . PT gramedia

Reid, G., 2009. Memotivasi Siswa di Kelas. Gagasan dan Strategi. Diterjemahkan oleh Hartati Widiastuti. PT Indeks Permata Puri Media, Jakarta Barat 11610.

Sagala, S., 2013. Manajemen Strategik dalam Peningkatan Mutu Pendidikan. Bandung: Alfabeta,CV.

Sallis, E., 2011, Total Quality Management in Education. Manajemen Mutu Pendidikan. Jogyakarta : IRCiSoD

Schunk, ad el, 2012. Motivasi dalam Pendidikan. Teori Penelitian dan Aplikasi. Diterjemakan oleh Ellys Tjo. PT Indeks Permata Puri Media, Jakarta Barat 11610.

Soedijarto, 2008. Tercapainya Tujuan Pendidikan Nasioanal Sebagai Ukuran bagi Pendidikan yang Bermutu dan Implikasinya. Jurnal Pendidikan Penabur. No 11/Tahun ke -7/ Desember 2008.

Suhaimi, U., 1999, Focus Group Discussion . Panduan Bagi Peneliti Studi Kualitatif Studi Dampak Sosial Krisis Moneter. Kerjasama BPS-ADB

Sukmadinata, N.S., 2008. Pengendalian Mutu Pendidikan Sekolah Menengah. Bandung. PT Refika Aditama.

Sunarko, 2009. Persepsi Peserta didik Tentang Pencitraan Sekolah (SMK) di Kabupaten Trenggalek. Jurnal Tehnologi Dana Kejuruan, Vol. 32, No. 2, September 2009

Trimantara, P., 2007. Sekolah Unggulan: Antara Kenyataan dan Impian. Jurnal Pendidikan PenaburNo 08/Th.VI/Juni 2007. 